\title{
Dari Teodisi dan Antropodisi Menuju Teo-antropodisi: Mengasihi Allah dan Sesama di Tengah Pandemi COVID-19
}

\section{From Theodicy and Anthropodicy to Theo-anthropodicy: Loving God and Loving Others Amid the COVID-19 Pandemic}

\author{
Tony Wiyaret Fangidae \\ Sekolah Tinggi Filsafat Theologi Jakarta \\ tony.fangidae@stftjakarta.ac.id
}

\begin{abstract}
Abstrak: Dunia sedang berhadapan dengan pandemi COVID-19 yang menyebabkan penderitaan di beberapa aspek kehidupan manusia seperti kesehatan, sosial, ekonomi, psikologis, hingga religius. Polemik ini menghantar kita pada diskusi seputar teodisi. Teodisi merupakan paradigma yang digunakan Leibniz untuk membela kemahabaikan dan kemahakuasaan Allah di hadapan realitas penderitaan, tetapi teodisi cenderung berhenti pada ranah teori tanpa praktik. Sontag mengusung paradigma antropodisi dalam wujud solidaritas sosial yang mengedepankan praktik untuk mengkritik teodisi yang terlampau abstrak dalam membela Allah tanpa mempedulikan penderitaan manusia. Antropodisi tampaknya terlalu sosialis dan cenderung berpegang pada kemampuan manusia, sehingga mengeksklusi aspek religius dalam solidaritas sosial. Levinas merespons kegelisahan ini dengan mengusung teodisi etis. Paradigma teodisi etis digunakan Levinas untuk memperlihatkan kehadiran Allah melalui manusia yang bertanggung jawab terhadap penderitaan sesamanya. Artikel ini mengusulkan nama, pemaknaan, dan pengembangan baru terhadap teodisi etis, yaitu teo-antropodisi, sebagai paradigma yang merangkul teodisi sekaligus antropodisi. Teo-antropodisi mengorelasikan teori dan praktik tersebut sama seperti iman (teodisi), tanpa perbuatan (antropodisi) adalah mati. Teo-antropodisi berfondasikan prinsip "mengasihi Allah dengan segenap hati, jiwa dan akal budi" serta "mengasihi sesama manusia seperti diri sendiri."
\end{abstract}

Kata-kata kunci: Teodisi, Antropodisi,Teodisi Etis, Teo-antropodisi, Leibniz, Sontag, Levinas, COVID-19, Penderitaan.

\begin{abstract}
The world is dealing with a COVID-19 pandemic that causes suffering in several aspects of human life such as health, social, economic, psychological, and religious. This polemic leads us to a discussion around theodicy. Theodicy is a paradigm Leibniz used to defend God's benevolence and omnipotence in front of the reality of suffering, but the theories tend to stop in the realm of theory without practice. Sontag carries the paradigm of anthropodicy in the form of social solidarity that promotes the practice of criticizing the overly abstract theodicy in defense of God regardless of human suffering. Anthropodicy seems to be too socialist and tend to hold on to human abilities, thus excluding the religious aspect in social solidarity. Levinas responded to this anxiety by carrying an ethical theodicy. The ethical theodicy paradigm is used by Levinas to demonstrate God's presence through humans who took responsibility for alleviating the suffering of his neighbor. This article proposes a new name, meaning, and development of ethical theodicy, namely theo-anthropodicy, as a paradigm that embraces both theodicy as well as anthropodicy. Theo-anthropodicy correlates these theories and practices in the same way that faith (theodicy), without action (anthropodicy) is dead. Theo-anthropodicy is based on the principles of "loving God with all your heart, soul and mind" and "loving others as yourself."
\end{abstract}

Keywords: Theodicy, Anthropodicy, Ethical Theodicy, Theo-anthropodicy, Leibniz, Sontag, Levinas, COVID-19, Suffering. 


\section{PENDAHULUAN}

Indonesia kembali bergumul dengan penderitaan, kali ini akibat pandemi COVID-19. COVID-19 ditemukan pertama kali di Wuhan, China, lalu menular ke hampir seluruh bagian dunia. Pada 31 Januari 2020, Dr. Tedros sebagai Direktur Jenderal Organisasi Kesehatan Dunia (World Health Organization) menyatakan darurat kesehatan publik di kancah internasional (Public Health Emergency of International Concern) akibat COVID-19. ${ }^{1}$ Per 13 November 2020, tercatat 51.848.261 orang terinfeksi dan 1.280 .868 orang meninggal akibat virus ini dari data 220 negara. $^{2} \mathrm{Di}$ Indonesia sendiri, per 13 November 2020, tercatat 452.291 orang terinfeksi, 382.084 orang sembuh, dan 14.933 orang meninggal akibat virus ini. ${ }^{3}$ Virus ini bukan saja melumpuhkan dan menyerang aspek kesehatan, tetapi juga beberapa aspek lain seperti sosial, ekonomi, psikologis, hingga religius. ${ }^{4}$ Tidak ada yang menduga virus ini bisa begitu melumpuhkan berbagai sendi kehidupan manusia.

Kelumpuhan sendi-sendi kehidupan membuat manusia menderita. Penderitaan manusia

\footnotetext{
${ }^{1}$ World Health Organization, "COVID-19 Public Health Emergency of International Concern (PHEIC) Global Research and Innovation Forum," https://www. who.int/who-documents-detail/covid-19-public-healthemergency-of-international-concern-(pheic)-globalresearch-and-innovation-forum, diakses 1 Mei 2020.

${ }^{2}$ Lih. "WHO Coronavirus Disease (COVID-19) Dashboard," https://covid19.who.int, diakses 13 November 2020.

${ }^{3}$ Data ini mengacu pada update per hari yang dikeluarkan Badan Penanggulangan Bencana Gugus Tugas Percepatan Penanganan COVID-19 (https://covid19.go.id/ peta-sebaran, diakses 13 November 2020).

${ }^{4}$ Adi Hidayat Argubi, "Virus Corona: Dampak Wabah Covid-19 Pada Sektor Kesehatan, Pendidikan, Sosial, Ekonomi Hingga Aktivitas Beribadah di Masyarakat," Kabar Harian Bima, https://kahaba.net/opini/76280/virus-coronadampak-wabah-covid-19-pada-sektor-kesehatanpendidikan-sosial-ekonomi-hingga-aktivitas-beribadah-dimasyarakat.html, diakses 1 Juni 2020. Bdk. dokumen dari Inter-Agency Standing Committee (IASC), Operational Considerations for Multisectoral Mental Health and Psychosocial Support Programmes during the COVID-19 Pandemic (IASC Reference Group MHPSS, Mei 2020), 26-27, yang memperlihatkan dampak COVID-19 pada beberapa sektor, khususnya kesehatan mental pada anak, keluarga, dan orang lanjut usia.
}

mengantarnya untuk mempertanyakan kehadiran Allah. Isu-isu yang mempertanyakan kehadiran Allah menggiring kita pada persoalan teodisi (keadilan Allah). Ross Douthat dalam bagian opini di surat kabar New York Times meyakini bahwa COVID-19 membangkitkan perdebatan terkait teodisi di jagat teologi dan filsafat. Pertanyaan-pertanyaan seputar isu teodisi muncul bertubi-tubi, misalnya: apakah dengan adanya pandemi ini, kita masih bisa mempercayai Allah yang baik dan mengasihi manusia? ${ }^{5}$ Di surat kabar Satu Harapan, Martin Lukito Sinaga, seorang pendeta sekaligus dosen di salah satu sekolah teologi, turut menghubungkan COVID-19 dengan isu teodisi melalui pertanyaan: "Di manakah Tuhan di tengah keadaan pandemi hari-hari ini?" Keterhubungan COVID-19 dan teodisi memanas belakangan ini dan menjadi perdebatan yang menarik untuk ditelusuri.

John Lennox dalam bukunya "Where is God in a Coronavirus World?" turut menyinggung isu teodisi dan berusaha meresponsnya. Lennox meyakini bahwa kehendak bebas manusia yang cenderung memilih kejahatan dan kekerasanlah yang mengakibatkan sakit-penyakit menimpa manusia seperti gempa bumi, tsunami, kanker, dan pandemi COVID-19. Semua itu terjadi karena hukuman Allah. ${ }^{7}$ Perspektif Lennox tampaknya berakar kuat pada teodisi yang diusung Gottfried Wilhelm Leibniz yang menyalahkan ketidaksempurnaan ciptaan sebagai penyebab penderitaan di dunia. ${ }^{8}$

${ }^{5}$ Ross Douthat, "The Pandemic and the Will of God," The New York Times, https://www.nytimes.com/2020/04/11/ opinion/sunday/coronavirus-religion.html, diakses 1 Mei 2020.

${ }^{6}$ Martin Lukito Sinaga, "Di Manakah Tuhan?" Satu Harapan, http://www.satuharapan.com/read-detail/read/dimanakah-tuhan, diakses 26 Mei 2020.

${ }^{7}$ John Lennox, Where Is God in a Coronavirus World?, terj. Budianto Lim (Surabaya: Literatur Perkantas Jawa Timur, 2020), 47-54.

${ }^{8}$ Paul Rateau, "The Problem of Evil and the Justice of God," dalam The Oxford Handbook of Leibniz, ed. Maria Rosa Antognazza (Oxford: Oxford University Press, 2018), 114 . 
Ketidaksepakatan terhadap paradigma teodisi Leibniz berdatangan, salah satunya dari Frederick Sontag. Sontag mengusung antropodisi sebagai solusi ketika manusia berhadapan dengan realitas penderitaan. Antropodisi mengedepankan solidaritas sosial di tengah penderitaan. ${ }^{9}$ Sayangnya, antropodisi seolah menegasi aspek religius atau spiritual di tengah penderitaan. Solusi lain dikemukakan Emmanuel Levinas dengan mengusung paradigma teodisi etis. Teodise etis merupakan panggilan moral untuk bertanggung jawab terhadap penderitaan orang lain. ${ }^{10} \mathrm{Di}$ dalam tanggung jawab tersebut, kita berjumpa dengan wajah Allah pada wajah sesama atau orang lain, karena tanggung jawab pada Allah harus mendapat bentuk konkret yang mewujud dalam tanggung jawab kepada sesama. $^{11}$

Artikel ini berusaha mengembangkan paradigma teodisi etis Levinas yang sebenarnya turut membela kasih Allah di tengah penderitaan dengan mengusung paradigma teoantropodisi. Teo-antropodisi merupakan solusi alternatif bagi teodisi yang cenderung berbicara tentang Allah, sehingga mereduksi hal-hal yang bersifat praktik, dan antropodisi yang terlalu sosialis, sehingga mengeksklusi ruang religiositas atau spiritualitas di tengah penderitaan. Teo-antropodisi berusaha membuktikan bahwa kasih Allah nyata di tengah pandemi atau new normal ${ }^{12}$ dari COVID-19 yang menyerang aspek kesehatan, kehidupan sosial, ekonomi, psikologis, hingga religius

${ }^{9}$ Frederick Sontag, "Anthropodicy and the Return of God," dalam Encountering Evil: Live Options in Theodicy, ed. Stephen Davis (Atlanta: John Knox, 1981), 137-151.

${ }^{10}$ Daniel J. Fleming, "Flight, Emmanuel Levinas, and the Critique of Theodicy," The Journal of Religion and Popular Culture 28, no. 1 (2016): 11-12, https://doi.org/10.3138/ jrpc.28.1.3150.

${ }^{11}$ Kosmas Sobon, "Konsep Tanggung Jawab Dalam Filsafat Emmanuel Levinas," Jurnal Filsafat 28, no. 1 (2018): 68, https://doi.org/10.22146/jf.31281.

${ }^{12} \mathrm{New}$ normal tidak berarti secara otomatis mengakhiri penderitaan manusia akibat COVID-19. Dalam pengamatan penulis, new normal merupakan wujud dari kehidupan di tengah pandemi COVID-19. seseorang baik yang terinfeksi virus tersebut maupun yang mengalami akibat tidak langsungnya. Teo-antropodisi mengusung pembelaan terhadap kasih Allah dengan mengedepankan kasih bagi sesama. Artikel ini menawarkan paradigma teo-antropodisi yang mengklaim bahwa: teo-antropodisi mampu memperlihatkan bahwa kasih Allah dan kasih bagi sesama termanifestasi melalui sokongan kesehatan, solidaritas publik, bantuan ekonomi, topangan psikologis, hingga bimbingan spiritual di tengah pandemi COVID-19.

Artikel ini akan dimulai dengan menguraikan teodisi ala Leibniz dan mencoba memosisikan paradigma teodisi Leibniz ini di tengah pandemi COVID-19; dilanjutkan dengan menelaah antropodisi ala Sontag dan Yonky Karman, dan mencoba memosisikan paradigma antropodisi itu di tengah pandemi COVID-19. Setelah itu, artikel ini menganalisis teodisi etis Levinas untuk dikembangkan sebagai teo-antropodisi yang mampu merangkul teodisi dan antropodisi di tengah penderitaan akibat COVID-19. Teo-antropodisi menjadi solusi alternatif bagi kehidupan religius untuk merelevansi dirinya di tengah pandemi COVID-19.

\section{DARI TEODISI DAN ANTROPODISI MENUJU TEO-ANTROPODISI}

Teori tanpa praktik tidak akan mendatangkan perubahan atau transformasi apa pun pada sendi-sendi kehidupan manusia. Teori adalah janji dan praktik adalah pembuktian dari janji tersebut. Setiap janji harus dibayar, seperti teodisi yang tidak dapat bertahan tanpa antropodisi dan sebaliknya. Teodisi dan antropodisi mesti hidup bersama dalam jalinan mesra teo-antropodisi sebagai perwujudan kasih Allah dan sesama yang mentransformasi sendi-sendi kehidupan manusia.

\section{Paradigma Teodisi ala Leibniz}

Teodisi berasal dari dua kata Yunani, yaitu Theos (Allah) dan dike (keadilan). Teodisi 
berarti keadilan Allah. ${ }^{13}$ Diskusi seputar isu ini sebenarnya sudah bermula di teks-teks kuno, misalnya di dalam Alkitab, kita menemukan cerita mengenai Ayub sebagai seorang yang jujur dan saleh, tetapi menderita. ${ }^{14}$ Pembahasan mengenai realitas penderitaan terus berkembang dan tiba pada perbincangan mengenai teodisi yang dipelopori Leibniz. ${ }^{15}$ Artikel ini hanya akan berfokus ke salah satu teodisi, yaitu yang diusung Leibniz, dengan tetap menghargai kekayaan diskusi mengenai teodisi lainnya.

Leibniz merupakan orang pertama yang memperkenalkan kata teodisi dalam bukunya Théodicée (1710). Tujuan teodisi Leibniz adalah membela kemahabaikan dan kemahakuasaan Allah di hadapan penderitaan. Pembelaan ini terbagi dalam dua penjelasan,

\footnotetext{
${ }^{13}$ Richard T.W. Arthur, Leibniz, Classic thinkers (Cambridge: Polity Press, 2014), 3-4.

${ }^{14}$ Kalis Stevanus, "Kesadaran Akan Allah Melalui Penderitaan Berdasarkan Ayub 1-2," DUNAMIS: Jurnal Teologi dan Pendidikan Kristiani 3, no. 2 (2019): 111-112, https://doi.org/10.30648/dun.v3i2.182. Pernalaran teodisi Leibniz berangkat dari pengaruh Agustinus. Salah satu perspektif Agustinus yang paling memengaruhinya adalah terkait kehendak bebas manusia atau ketidaksempurnaan ciptaan dapat menggiringnya untuk melakukan dosa. Irena Dorota Backus, Leibniz: Protestant Theologian (Oxford: Oxford University Press, 2016), 138.

${ }^{15}$ Perlu digarisbawahi bersama bahwa penggunaan istilah teodisi memang pertama kali digunakan oleh Leibniz, tetapi isu seperti ini telah didiskusikan cukup panjang sebelum tiba abad modern di zaman Leibniz. Epikuros (341-270 SM) pertama kali mendiskusikan isu semacam ini dengan menganjurkan beberapa premis menyangkut kehadiran Allah di tengah penderitaan. Pertama, Allah mahabaik, tetapi tidak mahakuasa, sehingga tidak mampu menegasi penderitaan. Kedua, Allah mahakuasa, tetapi tidak mahabaik, sehingga Allah tidak mau menegasi penderitaan. Ketiga, Allah tidak mahabaik dan tidak mahakuasa, sehingga penderitaan terus terjadi. Keempat, Allah mahabaik dan mahakuasa, tetapi premis ini rentan di hadapan penderitaan. Lih. Angela Longo, ed., Plotinus and Epicurus: Matter, Perception, Pleasure (Cambridge: Cambridge University Press, 2016), 74-75. Di ranah teologi Kristen, Agustinus merupakan salah seorang yang menggumuli persoalan ini. Adrea Poma berpandangan bahwa teodisi Leibniz dikembangkan dari pemikiran Agustinus. Lih. Andrea Poma, The Impossibility and Necessity of Theodicy: The "Essais" of Leibniz, Studies in German idealism, vol. 14 (Dordrecht: Springer, 2013), 33. Teodisi Leibniz secara khusus merujuk kepada aesthetic yang diusung Agustinus (ibid., 105).
}

pertama Allah dan kedua manusia (ciptaan). Kodrat Allah terbagi ke dalam tiga bagian, yaitu rasional (bijaksana), kehendak (tertuju pada kebaikan), dan mahakuasa (meng-adakan sesuatu). Leibniz berusaha merekonsiliasi ketiga kodrat Allah itu dengan kehendak bebas manusia yang terkadang menggiringnya melakukan keburukan. ${ }^{16}$

Kodrat rasional mengandaikan Allah tidak menciptakan dunia yang sempurna (tanpa kesalahan atau dosa), tetapi Allah telah menciptakan dunia yang terbaik dari segala kemungkinan dunia yang bisa Allah ciptakan. ${ }^{17}$ Leibniz menguraikan kemungkinan dunia yang terbaik ke dalam tiga komponen rasionalitas ilahi, yakni "yang mungkin", "yang aktual", dan "yang kondisional." Rasionalitas "yang mungkin" mengandaikan suatu hal berpotensi 'akan terjadi' (ide); rasionalitas "yang aktual" mengandaikan suatu hal 'harus terjadi'; rasionalitas "yang kondisional" mengandaikan suatu hal "terjadi tergantung kondisi' dari "yang mungkin" dan "yang aktual" demi kebaikan (kehendak anteseden) sebagai tujuan utamanya. ${ }^{18}$ Perspektif Leibniz ini tidak meniadakan penderitaan atau kemalangan dari rasionalitas Allah. Leibniz membuka peluang untuk eksistensi penderitaan di dalam "yang kondisional." Di dalam "yang rasional”, Allah berpotensi untuk memberlakukan penderitaan. Namun, penderitaan ini akan selalu bergantung pada kodrat "kehendak-Nya."

Kodrat kehendak Allah terbagi ke dalam dua kategori, yakni kehendak anteseden dan kehendak konsekuen. Kehendak anteseden merujuk kepada keinginan Allah agar manusia memperoleh kebaikan dan kehendak

\footnotetext{
${ }^{16}$ Shahin Avani, "Theodicy or Divine Justice in Leibniz," The Quaerterly Journal of Philosophical Investigations 14, no. 30 (2020): 2.

${ }^{17}$ Jan Levin Propach, "Leibniz's Worlds: The Connection between the Best Possible World and Monadic Realm," Synthesis Philosophica 34, no. 2 (2019): 423, https://doi.org/10.21464/sp34211.

${ }^{18}$ Vincentius Damar, Kejahatan dalam Dunia yang Terbaik (Yogyakarta: Kanisius, 2016), 64-65.
} 
konsekuen merujuk kepada potensi penderitaan yang terjadi karena manusia berlaku salah, sehingga memperoleh konsekuensi. Sebagai contoh, jika manusia membunuh sesamanya, konsekuensinya Allah menghukum pembunuh tersebut. ${ }^{19}$ Hukuman tersebut dapat dipandang sebagai sebentuk penderitaan. Walau demikian, Leibniz menegaskan bahwa penderitaan tersebut terjadi demi kebaikan yang lebih besar (greater good) bagi manusia, karena kodrat Allah yang konsekuen itu selalu bernegosiasi dengan yang anteseden untuk mendatangkan kebaikan. ${ }^{20}$

Kodrat Allah yang mahakuasa berkorelasi dengan kodrat Allah yang rasional dan kodrat Allah yang mahabaik. Allah yang mahakuasa berarti Allah berkuasa untuk menyatakan atau merealisasikan kehendakNya. Untuk merealisasikannya, kodrat Allah yang mahakuasa bergantung pada sesuatu "yang mungkin" dan "yang aktual." Untungnya, Allah yang mahakuasa ini selalu bernegosiasi dengan kehendak-Nya yang anteseden, ${ }^{21}$ sehingga Allah tidak menjadi sosok yang sewenang-wenang, karena Allah mendasari kemahakuasaan-Nya pada cinta-Nya kepada dunia. ${ }^{22}$ Dengan demikian, dunia yang ada saat ini adalah dunia yang terbaik dari pemahaman ideal Allah. ${ }^{23}$ Penderitaan yang diprakarsai Allah tidak bertujuan buruk, melainkan demi kebaikan. Kodrat Allah yang rasional dan mahakuasa, selalu berkompromi dengan kodrat-Nya yang anteseden, sehingga manusia senantiasa memperoleh

${ }^{19}$ Larry M. Jorgensen dan Samuel Newlands, ed., New Essays on Leibniz's Theodicy (Oxford: Oxford University Press, 2014), 75.

${ }^{20}$ Rateau, "The Problem of Evil and the Justice of God," 114.

${ }^{21}$ Gonzalo Rodriguez-Pereyra, Leibniz: Discourse on Metaphysics: Translated with Introduction and Commentary by Gonzalo Rodriguez-Pereyra (NewYork: Oxford University Press, 2020), 104-105.

${ }^{22}$ Paul Rateau, Leibniz on the Problem of Evil (New York: Oxford University Press, 2019), 326.

${ }^{23}$ Julia Weckend dan Lloyd Strickland, ed., Leibniz's Legacy and Impact, Routledge studies in seventeenthcentury philosophy 22 (New York: Taylor \& Francis, 2019), 55. kebaikan di dalam penderitaan. Akhirnya, manusia dapat mengamini bahwa penderitaan yang diprakarsai Allah berkontribusi untuk menata dunia menjadi lebih baik lagi. ${ }^{24}$

Hal itu diuraikan Leibniz lebih jauh dalam tulisannya A Most Perfect Being Exists. ${ }^{25}$ Leibniz memaparkan kesempurnaan kodrat Allah di hadapan ciptaan sebagai kesempurnaan yang tidak dapat dipahami manusia secara utuh. Namun, manusia dapat memastikan suatu keniscayaan, yaitu kesempurnaan Allah itu positif, sederhana, dan absolut. Allah hadir untuk menyatakan kebaikan (positif), menjumpai manusia dengan cara yang sederhana, dan secara absolut memaklumatkan kebaikan bagi ciptaan. ${ }^{26}$

Dalam penjelasannya mengenai manusia (ciptaan), Leibniz meyakini bahwa manusia diciptakan menurut gambar dan rupa Allah, tetapi berbeda secara signifikan, karena kehendak bebas manusia. Kodrat Allah sempurna, tetapi manusia tidak. Allah tidak mungkin "sama" seperti manusia "For God could not give creature all without making of it a God; therefore there must needs be different degrees in the perfection of things, and limitations also of every kind." 27 Leibniz menempatkan Allah sebagai sosok yang sempurna, sedangkan manusia terbatas.

Manusia memiliki kehendak bebas. Leibniz membaginya ke dalam tiga kategori, yaitu kehendak bebas akal budi, spontanitas, dan kontingensi. Kehendak bebas akal budi menuntun manusia untuk mengetahui baik/

${ }^{24}$ Nicholas Hadsell, "Leibniz's Horrendous and Unthinkable World: A Critique of Leibniz's 'Best Possible World' Theodicy," The Heythrop Journal (2019): 1, 5, https://doi.org/10.1111/heyj.13348.

${ }^{25}$ Teks aslinya berbunyi, "Perfectiones, sive formae simplices, sive qualitates absolutae positivae, sunt indefinibiles sive irresolubiles ... Perfectionem voco omnem qualitatem simplicem quae positiva est, et absoluta" (Propach, "Leibniz's Worlds," 417).

${ }^{26}$ Ibid., 418.

${ }^{27}$ Gottfried Wilhelm Leibniz, Theodicy, ed. Austin Farrer, terj. E. M. Huggard (Charleston: BiblioBazaar, 1985), 31. 
buruk tindakannya beserta konsekuensinya. Namun, ketidaksempurnaan ciptaan menyebabkan manusia tidak selalu memilih kebaikan. Kehendak bebas spontanitas berlaku ketika manusia melakukan sesuatu tanpa ada paksaan dari luar dirinya. Penderitaan berpotensi muncul dari kehendak bebas ini juga, karena manusia tidak mampu untuk selalu memilih kebaikan. Kehendak bebas kontingensi berlaku ketika manusia mengetahui kemungkinan-kemungkinan akibat dari tindakannya, tetapi potensi untuk memilih jalan yang buruk sangat besar. Singkatnya, Leibniz menempatkan kehendak bebas manusia sebagai penyebab penderitaan. Manusia mengetahui kebaikan, tetapi memilih untuk tidak melakukannya. ${ }^{28}$

Leibniz menyebut kehendak bebas manusia yang mengarah pada keburukan sebagai dosa. Kebaikan bukanlah tujuan dari dosa. Manusia tidak dapat menemukan kebaikan di dalam dosa, tetapi kejahatan. Ketika manusia berdosa, kodrat rasionalitas Allah "yang kondisional" berlaku dengan menghukum manusia. ${ }^{29}$ Hukuman ini bermaksud menghentikan kejahatan, mendidik, dan mendisiplinkan manusia-demi kebaikan yang lebih besar (kehendak anteseden). Leibniz terlihat membedakan dua jenis penderitaan: penderitaan dari Allah menuju kebaikan dan penderitaan dari manusia menuju kejahatan.

Selain itu, Leibniz berbicara menyangkut penderitaan yang datang dari natural evil. Pertama, di dalam komentarnya terhadap disertasi Johann Sturm, berjudul De Idolo Naturae (On Nature Itself), Leibniz menegaskan bahwa ada ketentuan yang sudah ditetapkan sejak semula dan melekat pada ciptaan, misalnya Allah memerintahkan makhluk hidup untuk terus berkembang biak dan tumbuhan menumbuhkan tunas-

\footnotetext{
${ }^{28}$ Damar, Kejahatan dalam Dunia yang Terbaik, 94-96. ${ }^{29}$ Rateau, "The Problem of Evil and the Justice of God," 114
}

tunas muda. Ketentuan ini bergerak terus menerus dan dapat mengakibatkan penderitaan di dalam kehidupan. Inilah yang disebut alamiah. ${ }^{30}$ Pada posisi ini, Leibniz mengkritisi perspektif Spinoza yang berpandangan bahwa Tuhan sama dengan alam (Deus Sive Natura), karena seolah yang terjadi di dunia ini hanya berasas pada ihwal natural. ${ }^{31}$ Leibniz menegaskan bahwa Allah tidak hadir begitu saja seperti alam. Allah hadir untuk mengintervensi kondisi-kondisi natural di dalam kehidupan yang berpotensi mengarah pada keburukan. Leibniz mengartikulasikannya sebagai berikut:

For the love of God also fulfills our hopes, and leads us down the road of supreme happiness, because by virtue of the perfect order established in the universe, everything is done in the best possible way, both for the general good and for the greatest individual good of those who are convinced of this. $^{32}$

Dengan mengkritisi Sturm dan Spinoza, Leibniz memisahkan secara eksplisit antara penderitaan yang alamiah, akibat kehendak bebas manusia, dan oleh Allah. Penderitaan Allah berfungsi mendisiplinkan dan bertujuan untuk kebaikan.

Leibniz menguraikan hal ini lebih lanjut dalam dokumen yang berisi dialognya dengan Baron Dobrzansky. Leibniz menulis bahwa manusia tidak sungguh-sungguh bebas. Kebebasan sempurna hanya milik Allah. Allah memiliki otoritas untuk mengintervensi kehendak bebas manusia yang mengarah pada kejahatan. Untuk itulah Allah menyiapkan sesuatu yang baik bagi ciptaannya. Kebebasan Allah yang sempurna itu

\footnotetext{
${ }^{30}$ Gottfried Wilhelm Leibniz, Philosophical Essays, ed. Roger Ariew, terj. Daniel Garber (Indianapolis: Hackett, 1989), 155, 158-159.

${ }^{31}$ Ibid., 165-166.

${ }^{32}$ Ibid., 212.
} 
bertujuan menata kehidupan yang mewujud dalam "dunia yang terbaik." ${ }^{3}$

Leibniz menutup persoalan ini dengan membahas kemungkinan dunia yang terbaik dari segala kemungkinan lain yang dapat Allah ciptakan. Dunia yang "terbaik" bukan berarti sempurna; yang "mungkin" bukan berarti sesuai dengan kebutuhan manusia; "dari kemungkinan lain" bukan berarti sesuai logika manusia. Semuanya menyatu di dalam "harmoni." 34 Dengan pernalaran seperti ini, di dalam Théodicée, sebagaimana dikutip Gian Luigi Paltrinieri, Leibniz menegaskan bahwa tidak mungkin membayangkan dunia yang terbaik tanpa rasa sakit dan penderitaan. ${ }^{35}$ Rasa sakit dan penderitaan akan terus ada, karena ketidaksempurnaan dunia dan kerentanan ciptaan. ${ }^{36}$

Leibniz menggarisbawahi bahwa bagaimana pun, karena Allah adalah "the most perfect mind," Allah tidak akan dipengaruhi oleh konsep harmoni yang terbaik, tetapi Allah mengidealkan sesuatu yang terbaik bagi ciptaan. ${ }^{37}$ Dengan pemahaman semacam ini, Leibniz mencoba menyelaraskan realitas penderitaan di hadapan kodrat Allah yang rasional (bijaksana), kehendak (tertuju pada kebaikan), dan mahakuasa (meng-ada-kan sesuatu)-yang selalu bertumpu pada kehendak-Nya yang anteseden.

Teodisi Leibniz secara jelas bertitik tolak pada satu tujuan, yaitu membela Allah

${ }^{33}$ Ibid., 111-113.

${ }^{34}$ Gian Luigi Paltrinieri, "Justifying Leibniz, or the Infinite Patience of Reasoning," PDF, in Theodicy and Reason, ed. Matteo Favaretti Camposampiero, and Luigi Perissinotto (Venezia: Università Ca' Foscari Venezia, 2016), 216.

${ }^{35}$ Ibid.

${ }^{36}$ Leibniz, Theodicy, 133-134.

${ }^{37}$ Gottfried Wilhelm Leibniz, Confessio Philosophi: Papers Concerning the Problem of Evil, 1671-1678, terj. Robert C. Sleigh (New Haven: Yale University Press, 2005), 3. Teks aslinya berbunyi: "Cum autem Deus sit mens perfectissima, impossibile est ipsum non affici harmonia perfectissima, atque ita ab ipsa rerum idealitate ad optimum necessitari” (ibid., 2, 117. A.II.i). kodrat Allah secara teoretis di hadapan penderitaan. Motif pembelaan semata-mata untuk mengamankan posisi iman dari goncangan para penganut ateisme, gnostik, atau skeptis yang mengklaim bahwa jika Allah ada, tidak mungkin ada penderitaan. Secara teoretis, Leibniz berhasil meyakinkan bahwa Allah ada di hadapan realitas penderitaan. Namun, teodisi semacam ini memiliki kekurangan di beberapa posisi, sebagaimana akan dibahas pada bagian antropodisi dan teodisi etis nantinya.

\section{Teodisi ala Leibniz dan COVID-19}

Sebelum atau setelah Leibniz memperkenalkan istilah teodisi, perdebatan dan solusi terkait realitas penderitaan sudah dan terus berkembang. Agar tidak terjebak dalam perdebatan teodisi yang amat luas, artikel ini hanya akan merespons penderitaan akibat COVID-19 berdasarkan teodisi Leibniz sebagaimana telah dibahas.

Leibniz mengakui bahwa dunia tanpa penderitaan adalah tidak mungkin. Leibniz terlihat memberi ruang bagi eksistensi penderitaan di tengah kehidupan manusia, bahkan COVID-19 sekalipun. Leibniz membuka dua kemungkinan penderitaan akibat COVID-19, yaitu penderitaan akibat kehendak bebas manusia dan kondisi natural (ketidaksempurnaan ciptaan).

Akibat kehendak bebas manusia dan ketidaksempurnaan ciptaan, virus seperti COVID-19 atau wabah lainnya berpotensi muncul dan berkembang. Manusia bukan makhluk sempurna yang tidak dapat merasakan sakit. Sakit menandakan kerapuhan dan kerentanan manusia sebagai ciptaan yang sungguh membutuhkan Allah. Keterlibatan Allah di dalam penderitaan semacam ini berpatokkan pada kehendak anteseden-Nya: Allah senantiasa menyediakan cinta-Nya untuk mengisi harapan manusia, menghantarkan manusia kepada kebahagiaan, karena dengan kehendak anteseden-Nya, 
Allah menyatakan segala sesuatu dengan cara yang terbaik. Itu berarti, Leibniz memberi suatu keniscayaan, yaitu pascapandemi, manusia akan melihat maksud Allah yang baik bagi dunia.

Teodisi Leibniz memosisikan Allah di dalam ruangan teoretis, sehingga mengikis kepedulian Allah di tengah penderitaan secara konkret. Leibniz berusaha menghibur orangorang yang menderita dengan mengklaim bahwa "kehendak Allah yang anteseden pasti menyertai setiap manusia di dalam penderitaannya." Di balik penderitaan itu, manusia diajar untuk mendisiplinkan diri di hadapan Allah dan berlaku baik. Allah niscaya akan memberikan "the greater good" bagi manusia. Teodisi Leibniz berusaha menaruh pengharapan yang besar di relung orang-orang yang beriman untuk meyakini bahwa "Allah menemani mereka di tengah pandemi COVID-19."

Sayangnya, teodisi Leibniz dipandang kurang memadai untuk menjawab problem penderitaan secara konkret dengan saling membantu secara ekonomi, saling merangkul secara sosial, dan saling menopang secara psikologis, karena teodisi Leibniz memang tidak bertujuan untuk menguraikan hal-hal yang bersifat praktik. Inilah salah satu kritik antropodisi dan teodisi etis yang akan dibahas nantinya. Teodisi Leibniz terlampau banyak berefleksi mengenai penderitaan, sehingga kurang mengimplementasi hasil refleksi terkait kepedulian Allah secara nyata. Alhasil, teodisi Leibniz yang kurang memberi ruang bagi praksis berteologi.

\section{Paradigma Antropodisi ala Sontag dan Karman}

Kritik terhadap Leibniz berdatangan. Salah satunya dari Frederick Sontag dalam artikelnya Anthropodicy or Theodicy? A Discussions with Becker's: The Structure of Evil dan sebuah bab dalam buku dengan judul $A n-$ thropodicy and the Return of God. Sontag berangkat dari pemahaman bahwa manusia dapat melakukan kesalahan. Kesalahan ini berlaku menurut ukuran ilmu pengetahuan, sehingga dapat diperbincangkan dan bukan kesalahan secara religius yang terkadang tidak dapat diukur oleh ilmu pengetahuan. ${ }^{38}$ Inilah cikal-bakal kejahatan menurut paradigma antropodisi. Kejahatan bukan berasal dari luar, melainkan dari manusia, sehingga manusia dapat mengukur dan mencari solusi terkait kesalahan-kesalahan yang diperbuatnya.

Sistem yang dikonstruksi antropodisi memosisikan manusia sebagai sentra. Kini paradigma tersebut berkembang menjadi antroposen (anthropocene). Antroposen merupakan pertanda beralihnya penyebab perubahan zaman, yaitu dari zaman es (holosen) menuju zaman manusia (antroposen). Manusia merupakan penyebab perubahan terhadap berbagai keadaan kehidupan, mulai dari iklim udara, kebersihan laut, dan sejumlah hal lain. Dengan tersentralisasi pada manusia, antropodisi memosisikan manusia sebagai penentu keadaan. ${ }^{39}$

Sontag meyakini bahwa manusia dapat menjelaskan cikal-bakal penderitaan, menelusurinya, dan menemukan jalan keluar penderitaannya. Perspektif ini menghantarnya untuk membela kehendak bebas manusia yang dipersoalkan teodisi. Teodisi telah menerapkan sebuah sistem dan struktur untuk menyalahkan kehendak bebas manusia. Padahal, kehendak bebas ini bukan saja dapat tertuju pada keburukan, tetapi juga kebaikan, sehingga kesalahan-kesalahan yang telah terjadi dapat direvisi. ${ }^{40}$

\footnotetext{
${ }^{38}$ Frederick Sontag, "Anthropodicy or Theodicy? A Discussion with Becker's: The Structure of Evil," Journal of the American Academy of Religion XLIX, no. 2 (1981): 267, https://doi.org/10.1093/jaarel/XLIX.2.267.

${ }^{39}$ Clive Hamilton, Defiant Earth: The Fate of Humans in the Anthropocene (London: Allen \& Unwin, 2017), 70.

${ }^{40}$ Sontag, "Anthropodicy or Theodicy," 273.
} 
Dengan ilmu pengetahuan, Sontag percaya bahwa manusia dapat melalui semuanya ini. Walaupun, Sontag menyadari bahwa keberagaman pengetahuan manusia tentang kebaikan dapat memicu penderitaan. Antropodisi dapat terealisasi hanya jika manusia memiliki kapasitas untuk melakukan kebaikan secara setara. Dengan demikian, setiap penderitaan dapat diobservasi, ditelaah, dan dianalisis oleh ilmu pengetahuan. Jika penderitaan tidak berada dalam ruang lingkup ilmu pengetahuan, maka manusia berpotensi untuk kembali kepada teodisi dengan berserah kepada Allah atau yang Sontag sebut sebagai the return of God. ${ }^{41}$ Untuk tidak kembali kepada Allah, manusia harus dapat menjelaskan dan mencari solusi atas penderitaannya sendiri.

Dengan mengeksklusi cikal-bakal penderitaan dan solusi terhadap penderitaan dari ihwal religius, antropodisi berusaha memosisikan kemandiriannya. Antropodisi tidak bergantung pada penderitaan dari luar, melainkan melihat penderitaan dari manusia sepenuhnya. Manusia dapat menjadi pelopor problem sekaligus solusi. Manusia dapat membangun kepedulian terhadap manusia lainnya dengan menciptakan jalan keluar bagi penderitaan manusia lain. Titik kepedulian itu yang disebut sebagai antropodisi. Antropodisi mewujud ketika manusia menderita dan manusia lain hadir untuk menghibur, menguatkan, dan memberi topangan. Antropodisi sangat berfokus pada hal-hal praktik untuk mengkonstruksi solidaritas sosial bagi sesama yang menderita.

Karman menilai bahwa konstruksi kepedulian antarmanusia merupakan kritik utama antropodisi terhadap teodisi. Bahasa teodisi tak menyentuh hati orang yang putus asa karena penderitaan. Teodisi terlalu sibuk meyakinkan logika rasio, hingga melupakan logika hati. Antropodisi sanggup menyentuh

\footnotetext{
${ }^{41}$ Sontag, "Anthropodicy and the Return of God," $137-151$.
}

hati korban kemalangan agar mereka dapat lebih leluasa mengekspresikan kepedihan mereka. Inilah yang dibutuhkan korban musibah yang tak bersalah. ${ }^{42}$ Antropodisi menyatakan keberpihakan pada manusia sebagai korban kemalangan. Keberpihakan antropodisi dapat mewujud secara konkret melalui topangan manusia lainnya.

Karman menilai bahwa wacana antropodisi lebih mampu menggalang solidaritas dan kebersamaan ketimbang teodisi. Antropodisi mampu melihat kemalangan dan penderitaan sebagai problem sosial, sehingga antropodisi mengusulkan praksis sosial untuk menanganinya. Karman menegaskan bahwa dalam konteks rakyat Indonesia yang masih terjebak sentimen primordial kesukuan dan agama, antropodisi lebih berguna dalam membangkitkan kesetiakawanan. ${ }^{43}$ Karman meyakini bahwa antropodisi dapat merangkul setiap golongan:

Kepedihan seorang ibu Kristen yang kehilangan buah hatinya sama dengan kepedihan ibu yang beragama lain. Rasa lapar seorang Kristen sama rasanya dengan rasa lapar orang yang bukan Kristen. Maka, tak ada alasan untuk diskriminasi dalam penderitaan. Wacana antropodisi perlu lebih dikembangkan sebagai salah satu landasan teoritis membangun solidaritas warga menuju Indonesia yang lebih baik. $^{44}$

Antropodisi secara kasat mata berpegang teguh pada kemampuan manusia untuk menciptakan kebaikan di tengah penderitaan. Bahkan, Karman meyakini bahwa kebaikan dari paradigma antropodisi dapat merangkul setiap golongan.

\footnotetext{
${ }^{42}$ Yonky Karman, "Antropodisi Dan Problematik Teodisi," Penuntun: Jurnal Teologi dan Gereja 11 (2010): 11-12.

${ }^{43}$ Ibid., 11-13.

${ }^{44}$ Ibid., 13.
} 
Alih-alih merangkul setiap golongan, antropodisi berpotensi untuk memicu sekat-sekat dalam solidaritas sosial, karena tidak didorong oleh hal-hal terkait agama. Solidaritas sosial berpotensi untuk menumpul jika agama tidak dilibatkan, karena agama memiliki keterhubungan erat dengan perilaku manusia. ${ }^{45}$ Manusia dapat bertindak (mis. bersolidaritas) dengan inspirasi dan motivasi agama. Itu berarti, agama tidak dapat dieksklusi begitu saja dari kehidupan, apalagi untuk mengupayakan kebaikan.

\section{Antropodisi Sontag dan Karman dan COVID-19}

Dalam kaitannya dengan COVID-19, antropodisi seolah meyakini bahwa dengan ilmu pengetahuan dan teknologi yang canggih, pandemi ini dapat ditangani atau solidaritas sosial untuk \#dirumahaja menjadi solusi terbaik menangani COVID-19. Karman mengakui bahwa konteks berpikir antropodisi dilatarbelakangi oleh penganut skeptisisme, agnostisisme, ateisme, bahkan yang mengklaim Allah-telah-mati. ${ }^{46}$ Hal ini berbanding terbalik dengan konteks Indonesia yang masih memercayai agama. COVID-19 mengonfirmasi bahwa antropodisi tidak begitu sukses, karena kurangnya dorongan agama untuk menyatakan solidaritas sosial sebagai upaya menghentikan penularan virus. Bahkan, beberapa gereja atau masjid masih beroperasi sebagai tempat beribadah seperti biasa di awal Maret. ${ }^{47}$ Solidaritas sosial sepertinya turut membutuhkan agama sebagai penggeraknya. Singkat kata, agama

${ }^{45}$ Charles A Kimball, When Religion Becomes Evil (New York: HarperCollins, 2008), 1.

${ }^{46}$ Karman, "Antropodisi Dan Problematik Teodisi," 11.

${ }^{47}$ Lih. "226 Dari 637 Jemaat GBI Di Lembang Positif Virus Corona," WARTAKOTAlive.com, https://warta kota.tribunnews.com/2020/04/04/mengejutkan-sebanyak226-dari-637-jemaat-gbi-di-lembang-positif-virus-corona, diakses 1 Juni 2020. Lih. juga "45 Masjid dan Musala Gelar Salat Berjamaah," RiauPos.co, https://riaupos.jawa pos.com/pekanbaru/01/05/2020/230567/45-masjid-danmusala-gelar-salat-berjamaah.html, diakses 1 Juni 2020. mampu menginspirasi, memotivasi, dan menggerakkan solidaritas sosial untuk menangani COVID-19.

\section{Paradigma Teodisi Etis ala Levinas}

\section{Kritik terhadap Teodisi dan Holocaust}

Emmanuel Levinas adalah seorang yang mengalami siksaan oleh Nazi dan melihat pembantaian terhadap orang Yahudi di kamp-kamp Nazi. Ia melihat orang-orang tak bersalah menderita. ${ }^{48}$ Joshua Shaw menaksir bahwa tulisan-tulisan Levinas seperti Totality and Infinity, Ethics and Infininity, Useless Suffering, atau bukubukunya yang lain merupakan responsnya terhadap penderitaan (mis. dalam bentuk holocaust $)^{49}$

Levinas berusaha mengkritisi penderitaan orang Yahudi yang cenderung dipahami menurut sudut pandang teodisi. Teodisi terlampau abstrak dan kebanyakan berteori. Levinas mengumumkan bahwa teodisi telah berakhir, karena gagal untuk menjelaskan penderitaan manusia. Teodisi tidak mampu memahami kebutuhan orang-orang yang menderita, seperti kasih sayang dan perhatian. ${ }^{50}$ Teodisi turut memosisikan orang yang menderita sebagai orang bersalah dan berdosa. Alasan-alasan teoretis paradigma teodisi telah memosisikan orang Yahudi yang sengsara akibat holocaust sebagai orang-orang yang layak menderita. Levinas

\footnotetext{
${ }^{48}$ Manuel Losada-Sierra, "Memory and History: The Overcoming of Traditional Theodicy in Levinas and Metz," Religions 10, no. 12 (2019): 5, https://doi.org/10. 3390/rel10120657. Levinas mengakui bahwa bibliografinya didominasi oleh pengalaman dan memori tentang Nazi, lih. Emmanuel Levinas, Difficult Freedom: Essays on Judaism (Baltimore: Johns Hopkins University Press, 1997), 291.

${ }^{49}$ Joshua Shaw, "Is Levinas's Philosophy a Response to the Holocaust?," The Journal of Jewish Thought and Philosophy 18, no. 2 (2010): 122-123, https://doi.org/10. 1163/147728510X529018.

${ }^{50}$ Michael Morgan, The Cambridge Introduction to Emmanuel Levinas (Cambridge: Cambridge University Press, 2011), 32.
} 
mengecam paradigma seperti ini, karena telah menyeret manusia kepada ketidakpedulian terhadap orang-orang yang menderita. Teodisi seolah melarang seseorang untuk bertanggung jawab bagi penderitaan yang lain, karena memandang penderitaan yang lain sebagai karya (hukuman) Allah. ${ }^{51}$

Teodisi berupaya merasionalkan penderitaan dan membela Allah. Levinas tidak menolak pembelaan terhadap Allah, tetapi pembelaan terhadap Allah tanpa tindakan etis merupakan sebuah kejahatan. ${ }^{52}$ Bahkan, Levinas mencela segala usaha untuk menjelaskan penderitaan dalam kungkungan rasionalitas belaka sebagai sumber pelanggaran moral. ${ }^{53}$ Levinas menjelaskan bahwa:

Theodicy as an attempt to explain suffering is meaningless ... a source of immorality. Suffering is linked to evil and therefore useless; it is unjustifiable by nature. However, suffering, and therefore theodicy, can find a meaning in ethics. Suffering has meaning as a subject taking upon itself the suffering of the other human. ${ }^{54}$

Penderitaan tidak bermakna apa pun jika tidak direspons atau penderitaan useless jika direspons dengan teodisi. Penderitaan diabaikan atau tidak dipedulikan, karena prinsipprinsip teodisi yang menganggap seseorang layak menderita. Penderitaan menjadi ruang kesepian, karena tanpa kepedulian orang lain.

Tragedi holocaust merupakan kejahatan, karena telah menyiksa, membunuh orang Yahudi, membenarkannya, dan memperlihatkan ketidakpedulian manusia melalui

\footnotetext{
${ }^{51}$ Jennifer Geddes, "Theodicy, Useless Suffering, and Compassionate Asymmetry: Primo Levi, Emmanuel Levinas, and Anti-Theodicy," Religions 9, no. 4 (2018): 6, https://doi.org/10.3390/rel9040114.

${ }^{52}$ Emmanuel Levinas, "Useless Suffering," in Entre Nous: Thinking-of-the-Other (New York: Columbia University Press, 1998), 99.

${ }^{53}$ Emmanuel Levinas, Entre Nous: Thinking of the Other (New York: Columbia University Press, 1998), 92.

${ }^{54}$ Losada-Sierra, "Memory and History," 2.
}

paradigma teodisi. Levinas berusaha merekonstruksi pemahaman tentang penderitaan dengan istilah mal dalam bahasa Perancis yang berarti rasa sakit dan kejahatan. Levinas menilai holocaust dipenuhi oleh rasa sakit dan kejahatan, sehingga ia menolak segala bentuk pembenaran terhadap penderitaan yang dialami orang Yahudi. ${ }^{55}$ Pembenaran itu hanya membela Allah yang mahabaik dan mahakuasa dengan menganggap bahwa orang Yahudi layak menderita, tanpa memedulikan rasa sakit yang mereka alami; pembenaran itu membungkam logika kritis untuk melihat holocaust sebagai mal yang diprakarsai Nazi; dan pembenaran itu seolah membujuk orang Yahudi yang menderita untuk pasrah menerimanya sebagai hukuman Tuhan. Teodisi yang memprakarsai pembenaran semacam ini gagal, karena telah salah arah. Teodisi bukan menjadi sarana pemulihan bagi orang-orang yang menderita, tetapi menjadi stigma bagi mereka sebagai orang-orang berdosa.

Jennifer Geddes dan Daniel J. Fleming sepakat untuk menyatakan bahwa penolakan Levinas terhadap teodisi menggambarkan dirinya sebagai seorang yang antiteodisi. ${ }^{56}$ Sierra menafsir sebaliknya. Ia menilai bahwa Levinas tidak mendeklarasikan dirinya sebagai seorang yang anti-teodisi. Levinas sedang menggiring teodisi ke arah yang berbeda, yaitu dari teodisi yang berteori (teodisi tradisional) menuju teodisi etis. ${ }^{57}$

Dari keprihatinannya terhadap penderitaan, Levinas membangun etika tanggung jawab sebagai respons etis terhadap penderitaan yang menolak respons teoretis yang diprakarsai teodisi tradisional. Baginya, yang terpenting dan krusial bukanlah berteori tentang

${ }^{55}$ Lisa Farley, "Useless Suffering: Learning from the Unintelligible and the Re-Formation of Community," Interchange (2004): 326.

${ }^{56}$ Fleming, "Flight, Emmanuel Levinas, and the Critique of Theodicy," 11; Geddes, "Theodicy, Useless Suffering, and Compassionate Asymmetry," 1.

${ }^{57}$ Losada-Sierra, "Memory and History," 6. 
penderitaan, melainkan respons etis untuk menangani penderitaan..$^{58}$ Dari sini kita menyaksikan bahwa teodisi etis berbeda dengan teodisi atau pun antropodisi, karena Levinas berusaha menggiring teodisi ke hal-hal yang bersifat praktik, sehingga pembelaan mengenai kebaikan dan kemahakuasaan Tuhan dapat dirasakan oleh orang-orang yang menderita. ${ }^{59}$ Levinas memilih cara-cara etis untuk menangani penderitaan ketimbang berteori tanpa bukti kepedulian etis.

Teodisi dalam pemahaman ini menutup ruang saling menopang dalam paradigma antropodisi. Pilihannya menjadi hitam-putih, yakni meyakini teodisi yang berangkat dari perspektif agama atau antropodisi dari perspektif sosialis. Bagian selanjutnya akan memperbincangkan kemungkinan bagi teodisi dan antropodisi berjalan bersama dalam etika tanggung jawab yang dikonstruksi Levinas.

\section{Tanggung Jawab: Wajah Yang Lain}

Levinas mengonstruksi etika tanggung jawab untuk merespons kegagalan teodisi di hadapan penderitaan orang Yahudi pada tragedi holocaust. Tanggung jawab selalu terarah kepada orang lain (yang lain), bahkan sebelum seseorang mengambil keputusan untuk bertanggung jawab atau tidak. ${ }^{60}$ Saat seseorang berjumpa dengan "wajah" ${ }^{61}$ yang lain, ia bertanggung jawab terhadapnya,

\footnotetext{
${ }^{58}$ Jennifer Geddes, "Theodicy, Useless Suffering, and Compassionate Asymmetry," 1-2.

${ }^{59}$ Joel Michael Reynolds, "Killing in the Name of Care," Levinas Studies 12 (2018): 154, https://doi.org/10. 5840/levinas20197163.

${ }^{60}$ Emmanuel Levinas, Otherwise than Being, or, Beyond Essence, terj. Alphonso Lingis (Pittsburgh: Duquesne University Press, 1978), 10-12.

${ }^{61}$ Ketika Levinas berbicara tentang "wajah", ia tidak sedang merujuk kepada "wajah" seseorang secara fisik, tetapi ia memperluas interpretasi terhadap "wajah" hingga kehadiran orang itu sendiri, kata-katanya, gambar, atau film. Lih. Emmanuel Levinas, Totality and Infinity: An Essay on Exteriority, Martinus Nijhoff Philosophy Texts, vol. 1, ed. ke-4 (Dordrecht: Kluwer Academic, 1991), 262, 269. Peter Atterton pun mendukung pemahaman tersebut
}

bahkan terhadap apa yang tidak dilakukannya. ${ }^{62}$ Itu berarti, tanggung jawab telah hadir secara eksistensial di dalam kehidupan manusia.

Tanggung jawab telah ada mendahului kebebasannya dan bukan dirinya yang memilih untuk bertanggung jawab. Tanggung jawab bukanlah sebuah keputusan yang dibuat seseorang atau kewajiban normatif atas tuntutan yang lain. Namun, seseorang menjadi subjek, karena bertanggung jawab atas yang lain. Jika René Descartes mendasari perspektif eksistensialnya pada cogito ergo sum, maka Levinas berfondasi pada respondeo ergo sum. ${ }^{63}$ Seseorang bukanlah subjek bagi dirinya (pour-soi), melainkan bagi yang lain-bahkan, bagi semua. ${ }^{64}$ Seseorang ada ketika ia bertanggung jawab bagi yang lain.

Levinas secara serius berbicara mengenai tanggung jawab bagi yang lain dalam konteks penderitaan. Seseorang bertanggung jawab atas penderitaan, luka, kepahitan, kemalangan, dan kesengsaraan yang lain. ${ }^{65}$ Levinas berpandangan bahwa penderitaan yang lain tidak akan berguna bagiku, tetapi penderitaanku yang merespons penderitaan yang lain dapat berguna dan bermanfaat. ${ }^{66}$ Levinas menegaskan bahwa "Its meaningfulness in me is only so in response to the other, a response that does not search for justification of their suffering or of the demand of my response to it." ${ }^{" 67}$ Tanggung jawab merupakan

dengan menyatakan bahwa Levinas tidak membatasi paradigma etikanya pada manusia, tetapi juga hewan (animals). Lih. Peter Atterton, "Levinas's Humanism and Anthropocentrism," dalam Oxford Handbook of Levinas, ed. Michael Morgan (Oxford: Oxford University Press, 2018), 709-710.

${ }^{62}$ Emmanuel Levinas, Ethics and Infinity, terj. Richard A. Cohen (Pittsburgh.: Dusquesne University Press, 1985), 95-96.

${ }^{63}$ Sobon, "Konsep Tanggung Jawab Dalam Filsafat Emmanuel Levinas," 66.

${ }^{64}$ Ibid., 61-63.

${ }^{65}$ Levinas, Otherwise than Being, or, Beyond Essence, $10-12$.

${ }^{66}$ Geddes, "Theodicy, Useless Suffering, and Compassionate Asymmetry," 6.

${ }^{67}$ Reynolds, "Killing in the Name of Care," 154. 
dasar eksistensinya dan menjadikan dirinya sebagai subjek yang menebus yang lain dari penderitaan. Tanggung jawab terhadap penderitaan yang lain berarti berusaha untuk memulihkannya dari derita tersebut. Pada proses pemulihan itu, subjek tersebut sedang memanusiakan manusia. ${ }^{68}$

Levinas menguraikan dua karakteristik tanggung jawab, yakni tanggung jawab yang bersifat konkret dan tanggung jawab yang bersifat asimetris. Tanggung jawab tidak dapat bersifat teoretis, karena subjek yang bertanggung jawab sungguh-sungguh konkret dan yang lain yang menderita bersifat konkret, sehingga tanggung jawab mesti bersifat konkret. ${ }^{69}$ Dengan demikian, seseorang tidak mungkin mengabaikan penderitaan yang lain, tetapi memilih untuk membantunya dalam proses pemulihan.

Levinas lebih menghargai tanggung jawab yang asimetris dan menolak tanggung jawab yang berlangsung dalam relasi timbal-balik atau mutualitas. Relasi mutualitas menuntut balasan ketika seseorang hendak bertanggung jawab bagi yang lain. Sistem balas budi tidak berlaku, karena seseorang yang bertanggung jawab bagi yang lain tidak mengharapkan yang lain akan melakukan hal serupa baginya. ${ }^{70}$ Seseorang yang bertanggung jawab tidak sedang meminjamkan "tanggung jawabnya" bagi yang lain, sehingga yang lain berhutang untuk mengembalikan kepada "tanggung jawab" tersebut. Tanggung jawab asimetris memungkinkan seseorang untuk bertanggung jawab dengan tulus, tanpa imbalan apa pun.

\section{Allah dan Tanggung Jawab bagi Yang Lain}

Etika tanggung jawab Levinas tidak terlepas dari ihwal agama atau Allah. Levinas memang

\footnotetext{
${ }^{68}$ Sobon, "Konsep Tanggung Jawab Dalam Filsafat Emmanuel Levinas," 67.

${ }^{69}$ Losada-Sierra, "Memory and History," 2.

${ }^{70}$ Levinas, Ethics and Infinity, 98-99.
}

mengklaim bahwa ia tidak sedang berteologi, ${ }^{71}$ tetapi memunculkan humanisme baru. $^{72}$ Namun, Levinas tidak melepaskan etika tanggung jawabnya untuk hidup tanpa Allah. Levinas menegaskan bahwa "the face of the other is the manifestation of the height in which God is revealed." "73 Levinas menguraikan penjelasan "wajah" yang terkorelasi dengan Allah dengan istilah diachronous. "Wajah" dalam pengertian ini mengandaikan seseorang yang ada bagi yang lain, hadir bersama dirinya (self) dan bersama diri yang absen. Diri yang absen ini memiliki jejakjejak (traces) untuk turut hadir bagi yang lain. Yang absen itu adalah Allah. Allah Yang Transenden termanifestasi melalui yang imanen ("wajah") atau yang lain merasakan Yang Transenden di dalam jejakjejak pada "wajah" yang imanen. ${ }^{74}$

Paradigma etika Levinas memperlihatkan bahwa Allah turut bertanggung jawab bagi yang lain: penderitaan, tangis, kemalangan, dan kepedihannya. Allah hadir sebagai Pribadi Ketiga (Third Person) yang mengekspresikan diri-Nya di dalam "wajah" untuk bertanggung jawab atas penderitaan. ${ }^{75}$ Itu berarti, saat seseorang hadir untuk bertanggung jawab bagi yang lain, ia tidak sendiri, tetapi turut memanifestasikan jejakjejak Yang Transenden.

Itu berarti, Levinas sebenarnya tidak melarang seseorang untuk menganut teodisi atau mengeksklusi teodisi. Levinas mengaku

\footnotetext{
${ }^{71}$ Kritiknya terhadap teologi semata-mata merujuk kepada teodisi yang terlampau abstrak dengan diskusidiskusinya, sehingga kurang menaruh perhatian pada praktik dari teologi itu. Michael Purcell, Levinas and Theology (Cambridge: Cambridge University, 2006), 51-53.

${ }^{72}$ Stephen Minister and Jackson Murtha, "Levinas and the Philosophy of Religion," Philosophy Compass 5, no. 11 (2010): 1026, http://doi.org/10.1111/j.1747-9991.20 10.00342.x.

${ }^{73}$ Levinas, Totality and Infinity, 199.

${ }^{74}$ Michael Morgan, "Levinas on God and the Trace of the Other," dalam Oxford Handbook of Levinas, ed. Michael Morgan (Oxford: Oxford University Press, 2018), 329-330.

${ }^{75}$ Ibid., 331-332.
} 
bahwa teodisi (tradisional) yang membenarkan penderitaan orang lain dilarang, tetapi ia mengatakan:

Saya tidak dapat melarang seseorang merespons penderitaannya dengan teodisi, karena jika saya melakukan itu, saya menolak kemungkinan seseorang untuk dapat memaknai penderitaannya dari sudut pandangnya. Mungkin penderitaannya dapat dilihatnya berguna baginya dari perspektif itu. Jika saya melarangnya untuk menganut teodisi, saya merampas haknya. Saya telah melakukan kekerasan terhadapnya. $^{76}$

Etika tanggung jawab ini bukanlah sebuah norma kehidupan, karena Levinas membuka ruang bagi teodisi untuk terus hidup, walau telah mengkritiknya habis-habisan. Levinas sekadar mengusulkan bagaimana manusia dan Allah secara ideal mestinya hadir di tengah kehidupan yang lain yang penuh penderitaan.

Levinas membuktikan bahwa Allah turut bertanggung jawab terhadap penderitaan manusia melalui kasih dari manusia yang lain. Itu artinya, Levinas tidak mengeksklusi Allah (theo) dan manusia (anthropos) di tengah penderitaan. Keduanya nyata di dalam tanggung jawab seorang bagi yang lain. Ini yang penulis sebut sebagai teoantropodisi, karena Levinas bukan saja mendorong teodisi etis, tetapi juga antropodisi. Teo-antropodisi menjadi solusi alternatif dalam konteks Indonesia yang masih berkeyakinan besar pada agama (Allah) untuk merespons penderitaan. Kehadiran seseorang di tengah penderitaan yang lain mewakili kehadiran manusia (seperti yang digaungkan antropodisi), tetapi turut memanifestasikan tanggung jawab Allah dalam wujud teoantropodisi.

\footnotetext{
${ }^{76}$ Geddes, "Theodicy, Useless Suffering, and Compassionate Asymmetry," 2.
}

\section{Paradigma Teo-antropodisi: Mengasihi Allah dan Sesama di Tengah Pandemi COVID-19}

Teodisi terlampau berteori mengenai Allah, sehingga mereduksi hal-hal yang bersifat praktik, sedangkan antropodisi mengedepankan praktik, tetapi mengeksklusi Allah. Padahal, keduanya bermanfaat untuk memulihkan dunia di tengah pandemi COVID19. Hal serupa diungkapkan Yakobus: "Sebab seperti tubuh tanpa roh adalah mati, demikian jugalah iman tanpa perbuatanperbuatan adalah mati." (Yak. 2:26). Iman direpresentasikan oleh teodisi, sedangkan perbuatan direpresentasikan oleh antropodisi. Oleh sebab itu, kesatuan teodisi dan antropodisi dibutuhkan untuk mewujudnyatakan transformasi dalam sendi-sendi kehidupan. Kesatuan itu terjalin dalam istilah teo-antropodisi.

Teo-antropodisi berfondasikan prinsip "mengasihi Allah dengan segenap hati, dengan segenap jiwa, dengan segenap akal budi dan dengan segenap kekuatan" (Ul. 6:5; Mat. 22:37; Mrk. 12:30; Luk. 10:27) serta "mengasihi sesama manusia seperti diri sendiri" (Im. 19:18; Mat. 19:19; Mrk. 12:31; Luk. 10:27; Rm. 13:9; Gal. 5:14; Yak. 2:8). ${ }^{77}$ Prinsip mengasihi Allah tampaknya telah tertanam di hati setiap orang yang beragama. Sayangnya, segregasi antaragama termanifestasi ketika kasih terhadap Allah diwujudnyatakan kepada sesama manusia (yang lain). Inilah keresahan Karman yang memengaruhinya untuk memilih antropodisi ketimbang teodisi atau mengeksklusi teodisi.

Karman menilai Indonesia masih terjebak dalam sentimen agama, sehingga tidak dapat menjalankan kasih Allah yang mewujud pada

\footnotetext{
${ }^{77}$ Penulis menggunakan kata "mengasihi" sebagai bentuk yang lebih spesifik dari kata "tanggung jawab" yang digunakan Levinas. Dengan kata lain, Levinas menggunakan kata "tanggung jawab" secara lebih luas, walau terarah dan terfokus. Penggunaan kata "kasih" ini juga lebih dekat dengan Kekristenan yang dikenal sebagai agama kasih.
} 
kasih terhadap sesama. Beberapa kritik terhadap Karman telah diuraikan, sekali lagi perlu digarisbawahi bahwa Karman mengeksklusi agama dalam solidaritas sosial untuk menangani penderitaan (mis. COVID19). Sentimen agama memang benar, tetapi hal itu tumbuh karena kepercayaan terhadap agama yang besar. Kepercayaan yang besar itu perlu diarahkan dan ditata sebagai sesuatu yang positif di tengah penderitaan, misalnya solidaritas publik.

Teo-antropodisi menawarkan arah baru dalam memandang agama karena tidak membatasi latar belakang suku, ras, atau agama apa pun untuk terlibat menangani COVID19. Teo-antropodisi mengikutsertakan agama sebagai penggerak dan pendorong partisipasi publik tersebut. Teo-antropodisi merupakan wujud dari karya kasih Allah di ruang publik melalui kasih sesama manusia yang tanpa sekat primordial tersebut. Karel Siahaya dkk. dalam artikel mereka Tuhan Ada di Mana-mana mencoba mengajak pembacanya untuk mengkritisi praktik beragama masing-masing (Kristen, Yahudi, atau Muslim), apakah praktik beragamanya berhenti pada aspek ritual atau mewujud dalam sosial umat manusia? ${ }^{78}$

Siahaya dkk. menegaskan bahwa agama hadir demi kebaikan manusia dan Tuhan turut mengilhami kebaikan (mis. keadilan sosial), tetapi cita-cita mulia itu sering berhenti akibat perdebatan mengenai dogma atau ajaran mana yang lebih benar ketimbang yang lain. Mereka menyimpulkan bahwa perdebatan mengenai Tuhan secara dogmatis tidak berarti bagi kebaikan dan kemajuan peradaban umat manusia dan dunia. Oleh sebab itu, Siahaya dkk. mengusulkan agar perdebatan dogmatis mengenai Tuhan diganti dengan dialog karya yang fungsional bagi kemajuan

\footnotetext{
${ }^{78}$ Karel Martinus Siahaya, Johannis Siahaya, dan Nunuk Rinukti, "Tuhan Ada Di Mana-Mana: Mencari Makna Bagi Korban Bencana Di Indonesia," Kurios: Jurnal Teologi dan Pendidikan Agama Kristen 6, no. 1 (April 2020): 108, https://doi.org/10.30995/kur.v6i1.147.
}

peradaban manusia, khususnya di tengah kehidupan global yang sering diwarnai bencana alam. ${ }^{79}$ Perspektif ini membantu kita untuk mengakhiri sekat-sekat agama di tengah pandemi COVID-19. Kita mengembalikan agama pada peran utamanya, yaitu menginspirasi, memotivasi, dan menggerakkan solidaritas publik di tengah pandemi ini, saling membantu secara ekonomi, saling merangkul secara sosial, dan saling menopang secara psikologis untuk menangani dampak buruk dari COVID-19.

Dengan demikian, kita mengamini bahwa Yang Transenden hadir di tengah pandemi COVID-19 ini melalui yang imanen sebagai wujud kasih-Nya atas apa yang dialami yang imanen. Yang Transenden itu tidak hanya di tamen Eden, Kemah Suci, Bait Allah, gereja, sampai kepada penciptaan langit dan bumi yang baru, ${ }^{80}$ tetapi juga melalui sesama manusia yang diciptakan menurut gambar dan rupa Allah. Dengan demikian, gambar dan rupa Allah tidak terdomestikasi pada manusia tertentu, tetapi bagi seluruh manusia dengan ciri fisik apa pun. ${ }^{81}$ Kita mengalami penyertaan dan perlindungan Allah melalui kehadiran sesama yang menyemangati "yang lain" yang terinfeksi, anjuran \#dirumahaja, atau para dokter, perawat, dan relawan mengambil risiko untuk mengorbankan hidup mereka sendiri untuk memberi pelayanan kesehatan terhadap orang-orang yang terinfeksi. Bahkan, Yang Transenden itu kita alami melalui kehadiran orang-orang yang merangkul secara sosial agar tidak ada wajah yang lain yang dieksklusi, membantu menunjang ekonomi yang lain yang mengalami PHK, menopang

\footnotetext{
${ }^{79}$ Ibid., 109-110.

${ }^{80}$ Martus Adinugraha Maleachi dan Hendra Yohanes, "Kehadiran Tuhan Di Tengah Umat-Nya: Dari Penciptaan Ke Penciptaan Yang Baru," Veritas: Jurnal Teologi dan Pelayanan 19, no. 1 (2020): 1-3, https://doi. org/10.36421/veritas.v19i1.361.

${ }^{81}$ Tony Wiyaret Fangidae, "Gambar Allah Menurut Kejadian 1: Sebuah Penolakan Terhadap Alienasi Subjek Dan Domestikasi Gambar Allah," Jurnal Theologia in Loco 2, no. 1 (2020): 111-114.
} 
orang-orang yang memiliki tekanan secara psikologis, atau para pendeta atau para ulama (dan profesi lainnya dalam agamaagama lain) yang membimbing secara spiritual orang yang bergumul dengan Allah di tengah pandemi ini.

Pada akhirnya, jika pertanyaan Douthat, Sinaga, atau Lennox kembali diutarakan "Di manakah Tuhan di tengah situasi pandemi hari-hari ini?" maka dengan paradigma teoantropodisi, kita mampu menjawab dengan lantang bahwa Tuhan ada di dalam kita yang hadir di tengah pandemi ini bagi yang lain. Allah hadir untuk menyatakan kasih-Nya melalui kasih sesama manusia. Allah tidak bungkam, berdiam, bahkan tidak perlu dibela di dalam skema atau sistem teoretis seperti yang ditawarkan teodisi atau tidak perlu dieksklusi seperti yang diusung antropodisi, karena Yang Transenden itu turut membuktikan kasih-Nya dalam wujud yang sangat konkret seperti sokongan kesehatan, solidaritas publik, bantuan ekonomi, topangan psikologis, dan bimbingan spiritual melalui kehadiran sesama manusia ("wajah") di tengah pandemi COVID-19. Hal itu menunjukkan bahwa kasih Allah Yang Transenden termanifestasi melalui yang imanen ("wajah") atau yang lain merasakan kasih Allah dalam bentuk yang konkret melalui Yang Transenden di dalam jejak-jejak pada "wajah" yang imanen.

\section{KESIMPULAN}

Artikel ini berusaha membuktikan bahwa teoantropodisi mampu memperlihatkan bahwa Allah telah, sedang, dan akan terus menyatakan kasih-Nya melalui "wajah" manusia di tengah pandemi COVID-19. Teo-antropodisi menegaskan bahwa penderitaan tidak mampu menegasi kasih Allah bagi umat-Nya. Manusia mengalami kasih Allah melalui sokongan kesehatan, solidaritas publik, bantuan ekonomi, topangan psikologis, dan bimbingan spiritual yang terus menyapa, merangkul, dan memulihkan manusia lainnya di tengah pandemi ini. Perspektif ini mendorong gereja untuk terus berkarya dalam sokongan kesehatan dengan membagi handsanitizer, masker, atau alat pelindung diri, membantu secara ekonomi orang-orang yang mengalami PHK, merangkul orang-orang yang tereksklusi, dan memberi bimbingan konseling bagi orang-orang mengalami kegelisahan dan kebimbangan secara spiritual. Dengan begitu, gereja menyatakan kasihnya bagi Allah dan bagi sesama sebagai wujud "wajah" Allah di tengah pandemi COVID-19.

\section{DAFTAR KEPUSTAKAAN}

Avani, Shahin. "Theodicy or Divine Justice in Leibniz." Journal of Philosophical Investigations 14, no. 30 (2020): 1-10.

Arthur, Richard T.W. Leibniz. Classic Thinkers. Cambridge: Polity Press, 2014.

Atterton, Peter. "Levinas's Humanism and Anthropocentrism." Dalam Oxford Handbook of Levinas, diedit oleh Michael Morgan, 710-731. Oxford: Oxford University Press, 2018.

Backus, Irena Dorota. Leibniz: Protestant Theologian. Oxford: Oxford University Press, 2016.

Damar, Vincentius. Kejahatan dalam Dunia yang Terbaik. Yogyakarta: Kanisius, 2016.

Fangidae, Tony Wiyaret. "Gambar Allah Menurut Kejadian 1: Sebuah Penolakan Terhadap Alienasi Subjek Dan Domestikasi Gambar Allah." Jurnal Theologia in Loco 2, no. 1 (2020): 91-117.

Farley, Lisa. "Useless Suffering: Learning from the Unintelligible and the ReFormation of Community." Interchange 35 (2004): 325-336. https://doi.org/10.10 07/BF02698881.

Fleming, Daniel J. "Flight, Emmanuel Levinas, and the Critique of Theodicy." The Journal of Religion and Popular Culture 28, no. 1 (2016): 11-22. https://doi.org/10. 3138/jrpc.28.1.3150.

Geddes, Jennifer. "Theodicy, Useless Suffering, and Compassionate Asymmetry: 
Primo Levi, Emmanuel Levinas, and Anti-Theodicy." Religions 9, no. 4 (2018): 1-8. https://doi.org/10.3390/rel9040114.

Hadsell, Nicholas. "Leibniz's Horrendous and Unthinkable World: A Critique of Leibniz's 'Best Possible World' Theodicy." The Heythrop Journal (2019): 1-7. https://doi.org/10.1111/heyj.13348.

Hamilton, Clive. Defiant Earth: The Fate of Humans in the Anthropocene. Sydney; Melbourne; London: Allen \& Unwin, 2017.

Inter-Agency Standing Committee. "Operational Considerations for Multisectoral Mental Health and Psychosocial Support Programmes during the COVID-19 Pandemic." IASC Reference Group MHPSS, Diakses pada 29 Mei 2020.

Jorgensen, Larry M., dan Samuel Newlands, ed. New Essays on Leibniz's Theodicy. Oxford: Oxford University Press, 2014.

Karman, Yonky. "Antropodisi Dan Problematik Teodisi." Penuntun: Jurnal Teologi dan Gereja 11 (2010): 1-14.

Kimball, Charles A. When Religion Becomes Evil. New York: HarperCollins, 2008.

Leibniz, Gottfried Wilhelm. Confessio Philosophi: Papers Concerning the Problem of Evil, 1671-1678. Diterjemahkan oleh Robert C. Sleigh. New Haven: Yale University Press, 2005.

—. Philosophical Essays. Diedit oleh Roger Ariew. Diterjemahkan oleh Daniel Garber. Indianapolis: Hackett, 1989.

—. Theodicy. Diedit oleh Austin Farrer. Diterjemahkan oleh E. M. Huggard. Charleston: BiblioBazaar, 1985.

Lennox, John. Where Is God in a Coronavirus World? Diterjemahkan oleh Budianto Lim. Surabaya: Literatur Perkantas Jawa Timur, 2020.

Levinas, Emmanuel. Difficult Freedom: Essays on Judaism. Baltimore: Johns Hopkins University Press, 1997.

- Entre Nous: Thinking of the Other. New York: Columbia University Press, 1998.
Ethics and Infinity. Diterjemahkan oleh Richard A. Cohen. Pittsburgh: Dusquesne University Press, 1985.

- Otherwise than Being, or, Beyond Essence. Diterjemahkan oleh Alphonso Lingis. Pittsburgh: Duquesne University Press, 1978.

- Totality and Infinity: An Essay on Exteriority. Martinus Nijhoff Philosophy Texts. Vol. 1. Ed. ke-4. Dordrecht: Kluwer Academic, 1991.

--___ "Useless Suffering." In Entre Nous: Thinking-of-the-Other, 91-101. New York: Columbia University Press, 1998.

Longo, Angela, ed. Plotinus and Epicurus: Matter, Perception, Pleasure. Cambridge: Cambridge University Press, 2016.

Losada-Sierra, Manuel. "Memory and History: The Overcoming of Traditional Theodicy in Levinas and Metz." Religions 10, no. 12 (2019): 1-19. https://doi.org/10. 3390/rel10120657.

Maleachi, Martus, dan Hendra Yohanes. "Kehadiran Tuhan Di Tengah UmatNya: Dari Penciptaan Ke Penciptaan Yang Baru." Veritas: Jurnal Teologi dan Pelayanan 19, no. 1 (2020): 11-24. https:// doi.org/10.36421/veritas.v19i1.361.

Minister, Stephen, and Jackson Murtha. "Levinas and the Philosophy of Religion." Philosophy Compass 5, no. 11 (2010): 1023-1033. https://doi.org/10.11 11/j.1747-9991.2010.00342.x.

Morgan, Michael. "Levinas on God and the Trace of the Other." Dalam Oxford Handbook of Levinas, diedit oleh Michael Morgan, 321-342. Oxford: Oxford University Press, 2018.

- The Cambridge Introduction to Emmanuel Levinas. Cambridge: Cambridge University Press, 2011.

Paltrinieri, Gian Luigi. "Justifying Leibniz, or the Infinite Patience of Reasoning." Dalam Theodicy and Reason: Logic, Metaphysics, and Theology in Leibniz's Essais de Théodicée (1710), diedit oleh Matteo Favaretti Camposampiero, Mattia Geretto dan Luigi Perissinotto, 
213-234. Venezia: Università Ca' Foscari Venezia, 2016.

Poma, Andrea. The Impossibility and Necessity of Theodicy: The "Essais" of Leibniz. Studies in German Idealism. Vol. 14. Dordrecht: Springer, 2013.

Propach, Jan Levin. "Leibniz's Worlds: The Connection between the Best Possible World and Monadic Realm." Synthesis Philosophica 34, no. 2 (2019): 415-431. https://doi.org/10.21464/sp34211.

Purcell, Michael. Levinas and Theology. Cambridge: Cambridge University Press, 2006.

Rateau, Paul. Leibniz on the Problem of Evil. Oxford: Oxford University Press, 2019. . "The Problem of Evil and the Justice of God." Dalam The Oxford Handbook of Leibniz, diedit oleh Maria Rosa Antognazza, 100-115. Oxford: Oxford University Press, 2018.

Reynolds, Joel Michael. "Killing in the Name of Care." Levinas Studies 12 (2018): 141-164. https://doi.org/10.5840/ levinas20197163.

Rodriguez-Pereyra, Gonzalo. Leibniz: Discourse on Metaphysics. New York: Oxford University Press, 2020.

Shaw, Joshua. "Is Levinas's Philosophy a Response to the Holocaust?" The Journal of Jewish Thought and Philosophy 18, no. 2 (2010): 121-146. https://doi.org/10.11 $63 / 147728510 \times 529018$.
Siahaya, Karel Martinus, Johannis Siahaya, and Nunuk Rinukti. "Tuhan Ada Di Mana-Mana: Mencari Makna Bagi Korban Bencana Di Indonesia." Kurios: Jurnal Teologi dan Pendidikan Agama Kristen 6, no. 1 (April 2020): 103-113. https://doi.org/10.30995/kur.v6i1.147.

Sobon, Kosmas. "Konsep Tanggung Jawab Dalam Filsafat Emmanuel Levinas." Jurnal Filsafat 28, no. 1 (2018): 47-73. https://doi.org/10.22146/jf.31281.

Sontag, Frederick. "Anthropodicy and the Return of God." Dalam Encountering Evil: Live Options in Theodicy, diedit oleh Stephen Davis, 137-151. Atlanta: John Knox, 1981.

—. "Anthropodicy or Theodicy? A Discussion with Becker's: The Structure of Evil." Journal of the American Academy of Religion XLIX, no. 2 (1981): 267-274. https://doi.org/10.1093/jaarel/ XLIX.2.267.

Stevanus, Kalis. "Kesadaran Akan Allah Melalui Penderitaan Berdasarkan Ayub 1-2." DUNAMIS: Jurnal Teologi dan Pendidikan Kristiani 3, no. 2 (2019): 111. https://doi.org/10.30648/dun.v3i2.182.

Weckend, Julia dan Lloyd Strickland, ed. Leibniz's Legacy and Impact. Routledge studies in Seventeenth-Century Philosophy. New York: Routledge, 2020. 